\title{
Epidemiological Trends of Rheumatoid Arthritis and PADI4, PTPN22, and HLA-DRB9 Genes Distribution in the Kazakhstan Population
}

\author{
Argul Issilbayeva $^{1,2 *}(\mathbb{D})$, Almagul Kushugulova ${ }^{1}$, Assel Meiramova ${ }^{1,2}$ (D) , Samat Kozhakhmetov ${ }^{1}$, Zhanar Akhmetova ${ }^{1,3}$ (D), \\ Madiyar Nurgaziyev ${ }^{1}$, Laura Chulenbayeva ${ }^{1}$, Dmitriy Babenko ${ }^{4}$, Jeannette Kunz $^{5}$ (D), Bayan Ainabekova ${ }^{2}$ (D) \\ ${ }^{1}$ Laboratory of Human Microbiome and Longevity, Center for Life Sciences, National Laboratory Astana, Nazarbayev University, \\ Nur-Sultan, Kazakhstan; ${ }^{2}$ Department of Internal Medicine with the Course of Gastroenterology, Endocrinology and Pulmonology, \\ NJSC Astana Medical University, Nur-Sultan, Kazakhstan; ${ }^{3}$ Department of Internal Medicine with Geriatrics course, NJSC \\ Astana Medical University, Nur-Sultan, Kazakhstan; ${ }^{4}$ Research Center, Karaganda Medical University, Karagandy, Kazakhstan; \\ ${ }^{5}$ Department of Medicine, School of Medicine, Nazarbayev University, Nur-Sultan, Kazakhstan
}

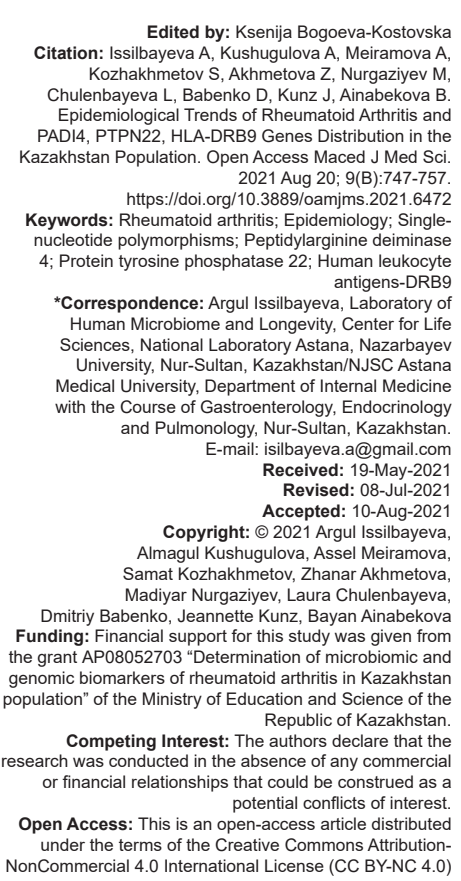

\section{Abstract}

BACKGROUND: The prevalence of rheumatoid arthritis (RA) is $1 \%$ in the global population. The lack of epidemiological studies in developing countries makes it difficult to obtain a complete global epidemiological picture of RA. RA develops due to the interaction of multiple genetic and environmental factors, though the contribution of these factors to the various disease occurrence seen in different populations is unclear.

AIM: The aim of our study was to analyze the dynamics of the general prevalence and incidence of RA among the population of Kazakhstan in 2017-2019 as well as to investigate the three most common single-nucleotide polymorphisms (SNP) of RA in the Kazakhstan population.

METHODS: The analysis of statistical data on Form 12 "On the health of the people and the health care system" was carried out. Prevalence and incidence rates were calculated according to generally accepted rules. Demographic data for the Republic of Kazakhstan were obtained from the official website stat.gov.kz. Our study included 70 RA patients and 113 control subjects. Blood samples were collected and genotyped for peptidylarginine deiminase 4 (PADI4), protein tyrosine phosphatase 22, and human leukocyte antigen (HLA)-DRB9 SNPs by reverse transcription polymerase chain reaction.

RESULTS: The prevalence of RA in Kazakhstan in 2017-2019 was 0.36-0.38\%, with an incidence rate of 0.085$0.087 \%$, which can be comparable to data of other countries in Central Asia. The allele and genotypes frequency analyses were carried out between patients and controls. The HLA-DRB9 showed significant association of the G allele odds ratio (OR) 1.96 (95\% confidence interval [Cl]: 1.252-3.081), $p=0.0025$ and $\mathrm{G} / \mathrm{G}$ genotype OR $=3.67(95 \%$ $\mathrm{Cl}$ : 1.58-8.54), $\mathrm{p}=0.00162$ with RA in our sample. Strong association between anti-citrullinated protein antibody (ACPA) profile and PADI4 (OR 12.19 [95\% CI: 2.19-67.94], $p=0.00115$ ) was found.

CONCLUSION: There was an increase in RA prevalence with age among females and a higher crude prevalence and incidence of RA in the southern regions of Kazakhstan. HLA-DRB9 prevailed in Kazakhstani patients with RA PADI4 showed association with ACPA-positive RA. Further studies on larger samples are required to confirm our obtained results.

\section{Introduction}

Worldwide, autoimmune diseases are the third most diagnosed medical condition after oncology and cardiology [1]. The same situation is true in Kazakhstan [2] where over a million Kazakhstan citizens suffer from autoimmune diseases.

Accordingtothelatestdata, theoverall prevalence of rheumatoid arthritis (RA) varies from $0.24-0.5 \%$ to up to $1 \%$ in the global population [3], [4], [5], [6], making it one of the most common autoimmune rheumatic diseases [7], [8], [9], [10], [11]. Women are 3-5 times more likely to be affected by this disease than men, and the initial symptoms of the disease can occur anywhere between 25 and 60 years of age [12], [13], [14]. Without timely diagnosis and treatment, this disease leads to progressive joint destruction, ankylosis, or sometimes death due to complications, and $40-70 \%$ of patients lose their ability to work while still of working age [15], [16], [17], [18].

Data from population studies indicate that there are 25-50 new cases of RA per 100,000 people in the world [7], [16]. The rate of premature death is 
significantly higher in patients with RA compared to the general population, causing significant reductions in life expectancy [9], [14], [17], [18].

Several epidemiological studies on RA have been performed, presenting a considerable variation in disease occurrence among different populations. Some ethnic and racial groups demonstrate an increased incidence of this disease compared to others [14], [19]. The highest incidence of RA 5.3\% has been observed among North American Pima Indians and 6.8\% among Southeast Alaska Indians [6], [20], while no RA cases have previously been reported among the rural population of Nigeria [21], [22] and the Aborigines of Australia [13].

According to some authors, there is a lower prevalence of RA in developing countries. Rudan et al. presented data indicating a prevalence of RA in low- or middle-income countries in Southeast Asia of $0.40 \%$, in East Europe of $0.37 \%$, in Europe of $0.62 \%$, in the Americas of $1.25 \%$, and in the West Pacific region of $0.42 \%$ [23]. The small number of epidemiological studies for most regions of the world and the lack of such studies in developing countries make it challenging to obtain a complete global epidemiological picture of RA.

According to data for 2013-2017, the total incidence of RA among the adult population in the Republic of Kazakhstan was 376.7 per 100,000 population, with a rise in prevalence of $69.1 \%$ [2].

While there are epidemiological trends in RA that is dependent on ethnicity and geographical location, the level of the risk is variable. RA is a genetic disorder that develops due to the interaction between multiple genetic, environmental, and lifestyle factors, and the mechanism of implication of these factors among different populations is not understood. The key role of more than 1000 genes in RA development has been conferred in several genome-wide association studies in major ancestries, though the ability of these results to be extrapolated to other populations is unclear. Along with the human major histocompatibility complex (MHC) human leukocyte antigens (HLAs) genes Class II genes, the strongest association was determined with non-HLA genes, the most widely being studied and discussed are the protein tyrosine phosphatase non-receptor type 22 (protein tyrosine phosphatase 22 [PTPN22]) and peptidyl arginine deiminase 4 (PADI4), which are effecting by amino acids change and contributing to worse RA prognosis [24], [25], [26], [27].

With these outstanding questions in mind, we initiated a study of the epidemiology of RA in the Republic of Kazakhstan for 2017-2019. This is the RA first prevalence study in Central Asia in general. The aim of this study was to analyze the dynamics of the prevalence and newly detected incidence of RA among the population of the Republic of Kazakhstan in 20172019 , as well as to investigate the prevalence of the three most studied MHC HLA genes in other populations with RA: PADI4, PTPN22, and MHC, Class II, DR beta 9 (HLA-DRB9).

\section{Materials and Methods}

\section{Epidemiological analysis}

An analysis of statistical data on Form 12 for collecting administrative data provided in accordance with the Code of the Republic of Kazakhstan "On the Health of the Nation and the Health care system" in the form of a report on the number of diseases registered in patients, living in the area of the medical organization service and the contingents of patients who are under dispensary supervision was carried out [28]. Prevalence and incidence were calculated according to the generally accepted rule that the number of registered cases of RA or number of $1^{\text {st }}$ time reported cases of $R A$ during the reporting period be divided by the average population and multiplied by 100,000 . Demographic data for the Republic of Kazakhstan were obtained from the official website of Agency for Strategic planning and reform of the Republic of Kazakhstan Bureau of National statistics [29]. Standardized indicators were calculated using the direct standardization method. $95 \% \mathrm{Cl}$ was calculated using the Clopper-Pearson method. The data for 2017 were used as a standard.

\section{Patients and controls}

The study sample comprised 70 female patients recruited in Nur-Sultan with an established diagnosis of RA and a disease duration of more than 1 year. Disease activity was evaluated with the Disease Activity Score in 28 Joints (DAS28) [30] and functional disability was assessed by the Health Assessment Questionnaire (HAQ) [31]. Inflammatory activity was evaluated using erythrocyte sedimentation rate (ESR) and $\mathrm{C}$-reactive protein (CRP). The $\mathrm{X}$-ray stage was set on the basis of X-ray images for the past year. Functional status stratified according to ability to perform usual activities of daily living (self-care, professional, and non-professional). A control group of 113 healthy female subjects with no individual or familial history of autoimmune diseases was included in the study. The study was performed in accordance with the rules and principles of the Helsinki Declaration; informed consent was obtained from all participants in the patient and control groups. Blood samples were collected from all participants in compliance with infection safety measures. Anti-citrullinated protein antibody (ACPA) and rheumatoid factor (RF) were measured with a second-generation enzyme-linked immunosorbent assay (ELISA). 


\section{Single-nucleotide polymorphism (SNP) analysis}

Genomic DNA was extracted from the collected whole blood of RA patients and healthy subjects to the test tubes with ethylenediaminetetraacetic acid (EDTA-ACID). The DNA isolation was performed using the Promega Wizard Genomic DNA Purification Kit designed for isolation of DNA from white blood cells (Promega Corporation 2800 Woods Hollow Road Madison, WI 53711-5399 USA) according to the manufacturer's standard protocol. All DNA were stored at $-20^{\circ} \mathrm{C}$ until tested. The samples were genotyped for the HLA-DRB9 rs9268839, PTPN22 rs2476601, and PADI4 rs2240340 variants, by real-time polymerase chain reaction (RT-PCR) using TaqMan technology according to the manufacturer's instructions (Applied Biosystems 7500, Foster City, CA).

\section{Statistical analysis}

Descriptive statistics were conducted according to generally accepted standards using the IBM SPSS Statistics 26 software program (IBM, USA; I). Comparison of genotype distribution and allele frequency between RA patients and healthy controls was evaluated by the Chi-square test, using an odds ratio (OR) and 95\% confidence interval $(95 \% \mathrm{Cl})$. Correlation of the associated SNP with autoantibody status among RA cases was performed with the Chisquare test. Patient and control genotype frequencies did not deviate from Hardy-Weinberg equilibrium. The comparison of clinical and laboratory parameters with the different genotypes was performed using a t-test and Chi-square test with Yate's correction when necessary. $p=0.05$ was considered statistically significant.

\section{Results}

\section{Kazakhstan \\ Epidemiological trends of RA in}

The absolute number of the Kazakhstan population (i.e., the population denominator) increased during the study period. The number of patients with RA showed the same overall trend, though the crude prevalence and crude incidence rates demonstrated a downward trend in 2018, as shown in Table 1 . The average prevalence of RA in Kazakhstan in 2017-2019 was $0.36-0.38 \%$, and the incidence was $0.085-0.087 \%$ (Table 1).

The highest rates of RA were observed in the age group of 60 years and older followed by the age group of 18-59 years. It should be noted that the largest proportion of the population of the Republic of Kazakhstan is in the 18-59 age group (Supplementary Table 1).
Table 1: Prevalence and incidence of RA in the Republic of Kazakhstan in 2017-2019

\begin{tabular}{|c|c|c|c|c|c|}
\hline \multicolumn{6}{|c|}{ Prevalence } \\
\hline Year & $\begin{array}{l}\text { Number of } \\
\text { reported RA } \\
\text { cases }\end{array}$ & Population & $\begin{array}{l}\text { Crude } \\
\text { estimate, per } \\
100,000\end{array}$ & $\begin{array}{l}\text { Crude } \\
\text { percentage } \\
(\%)\end{array}$ & $\begin{array}{l}\text { Standardized rate } \\
(95 \% \mathrm{Cl}) \ddagger\end{array}$ \\
\hline 2017 & 68,618 & $18,157,337$ & 377.9 & 0.38 & $376.4(373.6-379.2)$ \\
\hline 2018 & 66,647 & $18,395,567$ & 362.2 & 0.36 & $374.5(371.7-377.3)$ \\
\hline 2019 & 71,266 & $18,631,779$ & 382.5 & 0.38 & $382.8(379.9-385.6)$ \\
\hline \multicolumn{6}{|c|}{ Incidence } \\
\hline Year & $\begin{array}{l}\text { Number } \\
\text { of new RA } \\
\text { cases }\end{array}$ & Population & $\begin{array}{l}\text { Crude } \\
\text { estimate, per } \\
100,000\end{array}$ & $\begin{array}{l}\text { Crude } \\
\text { percentage } \\
(\%)\end{array}$ & $\begin{array}{l}\text { Standardized rate } \\
(95 \% \mathrm{Cl}) \ddagger\end{array}$ \\
\hline 2017 & 15,386 & $18,157,337$ & 84.7 & 0.085 & $84.7(83.4-86.1)$ \\
\hline 2018 & 15,498 & $18,395,567$ & 84.2 & 0.084 & $84.3(82.9-85.6)$ \\
\hline 2019 & 16,146 & $18,631,779$ & 86.7 & 0.087 & $86.7(85.4-88.1)$ \\
\hline
\end{tabular}

In the age group of 60 years and older, there was a significant increase in RA among males during the study period, though females continued to have a higher prevalence, with a female-to-male ratio in 2019 of 1.3:1. In the age group of 18-59, RA prevailed in females, with a female-to-male ratio of $3: 1$. In 2018, there was a decrease in RA prevalence in both females and males in the 18-59 age category, though in 2019, the prevalence of RA increased across the adult population of the Republic of Kazakhstan (Supplementary Table 1).

An increase in the absolute number of RA cases among females of all ages was noted from 2017 to 2019, though there was a decrease in crude prevalence and crude incidence in females in 2018 (Table 2).

Table 2: Prevalence and incidence of RA in 2017-2019 according to gender

\begin{tabular}{|c|c|c|c|c|c|c|c|c|}
\hline \multicolumn{5}{|c|}{ Prevalence among females } & \multicolumn{4}{|c|}{ Incidence among females } \\
\hline Year & $\begin{array}{l}\text { Number } \\
\text { of RA } \\
\text { cases }\end{array}$ & Population & $\begin{array}{l}\text { Crude } \\
\text { estimate } \\
\text { per 100,000 }\end{array}$ & $\begin{array}{l}\text { Crude } \\
\%\end{array}$ & $\begin{array}{l}\text { Number } \\
\text { of new } \\
\text { RA cases }\end{array}$ & Population & $\begin{array}{l}\text { Crude } \\
\text { estimate } \\
\text { per } \\
100,000\end{array}$ & $\begin{array}{l}\text { Crude } \\
\%\end{array}$ \\
\hline 2017 & 53,455 & $9,366,039$ & 571 & 0.57 & 11,417 & $9,366,039$ & 121.9 & 0.122 \\
\hline 2018 & 51,846 & $9,482,371$ & 547 & 0.55 & 11,468 & $9,482,371$ & 120.9 & 0.121 \\
\hline 2019 & 54,275 & $9,597,645$ & 566 & 0.57 & 11,860 & $9,597,645$ & 123.6 & 0.124 \\
\hline \multicolumn{5}{|c|}{ Prevalence among males } & \multicolumn{4}{|c|}{ Incidence among males } \\
\hline Year & $\begin{array}{l}\text { Number } \\
\text { of RA } \\
\text { cases }\end{array}$ & Population & $\begin{array}{l}\text { Crude } \\
\text { estimate } \\
\text { per } \\
100,000\end{array}$ & $\begin{array}{l}\text { Crude } \\
\%\end{array}$ & $\begin{array}{l}\text { Number } \\
\text { of new } \\
\text { RA cases }\end{array}$ & Population & $\begin{array}{l}\text { Crude } \\
\text { estimate } \\
\text { per } \\
100,000\end{array}$ & $\begin{array}{l}\text { Crude } \\
\%\end{array}$ \\
\hline 2017 & 15,163 & $8,791,298$ & 172.5 & 0.173 & 3969 & $8,791,298$ & 45.1 & 0.045 \\
\hline 2018 & 14,801 & $8,913,196$ & 166.1 & 0.167 & 4030 & $8,913,196$ & 45.2 & 0.045 \\
\hline 2019 & 16,991 & $9,034,134$ & 188.1 & 0.188 & 4286 & $9,034,134$ & 47.4 & 0.047 \\
\hline
\end{tabular}

The prevalence of RA among males decreased in 2018 to $0.17 \%$ of the population, then increased in 2019 to account for $0.19 \%$ of the population (Table 2 ). While the incidence among males increased over the analyzed period, on average, the female-to-male ratio of RA prevalence was 3:1.

When the prevalence and incidence of RA were analyzed by geographical region, the largest number of registered cases of RA was noted, including among females, in the Shymkent region. The smallest number of cases was reported in the Atyrau region. A definitive increase in reported cases was observed in the Akmola region during the study period, while in the Pavlodar and North Kazakhstan regions, there was a slight decrease in RA cases during the study period (Figure 1). There was a higher prevalence of $\mathrm{RA}$ in the southern regions of the 


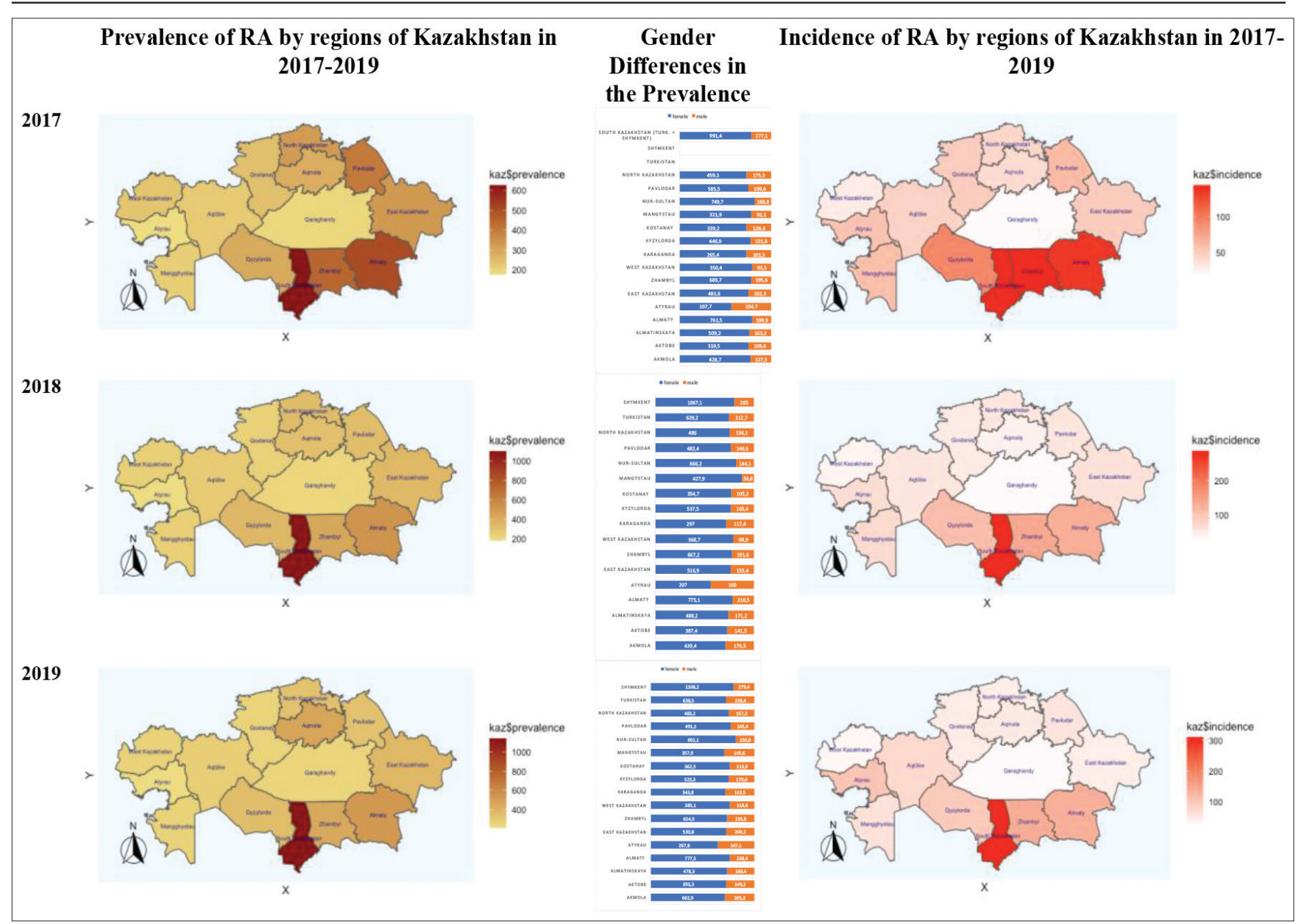

Figure 1: Prevalence and incidence rate of RA by region in Kazakhstan in 2017-2019

country compared to the northern regions. In terms of incidence, Shymkent also had the highest proportion, and the lowest proportion of incidence was noted in the Karaganda region (Figure 1 and Supplementary Tables 2 and 3).

\section{Clinical characteristics of patients with RA}

70 female patients with RA diagnosis were included in the main group of the study. Stratifying the sample according to disease type, $74.2 \%(n=52)$ of the women under the study were seropositive, while $25.8 \%(n=18)$ were seronegative. The $51.4 \%(n=36)$ had ACPA-positive and $48.6 \%(n=34)$ ACPA-negative variant of the disease. All clinical and biological characteristics of patients included in this study are summarized in Table 3.

The control group consisted of 113 matched healthy female subjects with the mean age of 39 (Q1Q3: 35-47.5) with no individual or familial history of autoimmune diseases. Informed consent was obtained from all patients and healthy subjects; the study was performed in accordance with the rules and principles of the Helsinki Declaration.
Table 3: Characteristic of patients with RA included in the study

\begin{tabular}{ll}
\hline Parameters & Number of patients $(\mathrm{n}=70)$ \\
\hline Mean age (years) & $47(\mathrm{Q} 1-\mathrm{Q} 3: 39-51)$ \\
Age of RA onset & $34.5(\mathrm{Q} 1-\mathrm{Q} 3: 26-43)$ \\
Disease duration (years) & $6(\mathrm{Q} 1-\mathrm{Q} 3: 3-12)$ \\
DAS28 score & $4.6 \pm 1.5(95 \% \mathrm{Cl}: 4.4-5.1)$ \\
HAQ score & $0.9 \pm 0.7(95 \%$ Cl: $0.8-1.2)$ \\
RF (IU/mL) & $52.1(\mathrm{Q} 1-\mathrm{Q} 3: 14.4-115.1)$ \\
ACPA $(\mathrm{U} / \mathrm{mL})$ & $33.4(\mathrm{Q} 1-\mathrm{Q} 3: 0.5-163.3)$ \\
CRP $(\mathrm{mg} / \mathrm{l})$ & $4.1(\mathrm{Q} 1-\mathrm{Q} 3: 0.9-7.7)$ \\
ESR (mm/h) & $23.5(\mathrm{Q} 1-\mathrm{Q} 3: 14-46)$ \\
RF positive $(\%)$ & $52(74.2 \%)$ \\
ACPA positive $(\%)$ & $36(51.4 \%)$ \\
Smokers & $3(4.2 \%)$ \\
X-ray stage & \\
I & $14(20 \%)$ \\
II & $30(42.8 \%)$ \\
III & $16(22.8 \%)$ \\
IV & $10(14.2 \%)$ \\
Functional status & \\
I & $19(27.1 \%)$ \\
II & $42(60 \%)$ \\
III & $8(11.4 \%)$ \\
IV & $1(1.4 \%)$ \\
Disease activity & \\
High & $27(38.5 \%)$ \\
Moderate & $32(45.7 \%)$ \\
Low & $6(8.5 \%)$ \\
Remission & $5(7.1 \%)$ \\
\hline
\end{tabular}

\section{Genetic factors}

A comparative analysis of individual allele and genotype frequencies between RA patients and control group was carried out. The allele distributions of HLA-DRB9, PTPN22, and PADI4 polymorphisms are 
presented in Table 4. According to the data presented in this table, G allele of HLA-DRB9 rs9268839 significantly prevailed in RA group compared to the control group, accounting for $57.9 \%$ and $41.2 \%$ of RA patients and controls, respectively ( $p=0.0025$; Table 4$)$.

Table 4: HLA DRB9, PTPN22, and PADI4 allele distribution

\begin{tabular}{llllll}
\hline SNP & Allele & $\begin{array}{l}\text { RA patients } \\
(n=70),(a b s . \%)\end{array}$ & $\begin{array}{l}\text { Control } \\
(n=113),(a b s . \%)\end{array}$ & OR $(95 \%$ Cl) & p value \\
\hline rs9268839* & A & $59(42.1)$ & $133(58.8)$ & 1.96 & $0.0025^{*}$ \\
HLA-DRB9 & G & $81(57.9)$ & $93(41.2)$ & $(1.252-3.081)$ & \\
rs2240340 & C & $74(52.9)$ & $140(61.9)$ & 1.45 & 0.102 \\
PADI4 & T & $66(47.1)$ & $86(38.1)$ & $(0.926-2.275)$ & \\
rs2476601 & G & $129(92.1)$ & $212(93.8)$ & $1.29(0.513-3.165)$ & 0.531 \\
PTPN22 & A & $11(7.9)$ & $14(6.2)$ & & \\
\hline
\end{tabular}

The frequencies of rs2240340 and rs2476601 alleles demonstrated no statistically significant difference between the patient and the control groups ( $p=0.102 ; p=0.531 ;$ Table 4).

The genotype distributions of HLA-DRB9, PTPN22, and PADI4 polymorphisms in RA patients and control groups are demonstrated in separate tables with multiple models of inheritance. The G/G genotype of rs9268839 HLA-DRB9 significantly prevailed in RA patients group compared to control group by codominant OR $=3.67(95 \% \mathrm{Cl} 1.58$ 8.54), $p=0.00162$ and recessive model OR $=3.55(95 \%$ Cl 1.75-7.18), $p=0.00034$ (Table 5). The log-additive model also revealed significant differences in genotypes between the RA patients and control groups OR = 1.92 (95\% Cl 1.25-2.96), $p=0.00232$ (Table 5).

Table 5: HLA-DRB9 genotype distribution

\begin{tabular}{|c|c|c|c|c|c|}
\hline $\begin{array}{l}\text { rs9268839 } \\
\text { HLA-DRB9 }\end{array}$ & Genotypes & $\begin{array}{l}\text { RA patients } \\
(\mathrm{n}=70), \\
(\mathrm{abs} . \%)\end{array}$ & $\begin{array}{l}\text { Control } \\
(n=113), \\
(\text { abs. \%) }\end{array}$ & OR $(95 \% \mathrm{Cl})$ & $p$ value \\
\hline Dominant & $\begin{array}{l}\mathrm{A} / \mathrm{A} \\
\mathrm{A} / \mathrm{G}-\mathrm{G} / \mathrm{G}\end{array}$ & $\begin{array}{l}16(22.9) \\
54(77.1)\end{array}$ & $\begin{array}{l}37(32.7) \\
76(67.3)\end{array}$ & $\begin{array}{l}1 \\
1.64 \\
(0.83-3.25)\end{array}$ & 0.14773 \\
\hline Codominant & $\begin{array}{l}A / A \\
A / G- \\
G / G\end{array}$ & $\begin{array}{l}16(22.9) \\
27(38.6) \\
27(38.6)\end{array}$ & $\begin{array}{l}37(32.7) \\
59(52.2) \\
17(15)\end{array}$ & $\begin{array}{l}1 \\
1.06(0.5-2.22) \\
3.67 \\
(1.58-8.54)\end{array}$ & $0.00162 *$ \\
\hline Recessive & $\begin{array}{l}\mathrm{A} / \mathrm{A}-\mathrm{A} / \mathrm{G} \\
\mathrm{G} / \mathrm{G}\end{array}$ & $\begin{array}{l}43(61.4) \\
27(38.6)\end{array}$ & $\begin{array}{l}96(85) \\
17(15)\end{array}$ & $\begin{array}{l}1 \\
3.55 \\
(1.75-7.18)\end{array}$ & $0.00034 *$ \\
\hline Overdominant & $\begin{array}{l}\text { A/A-G/G } \\
A / G\end{array}$ & $\begin{array}{l}43(61.4) \\
27(38.6)\end{array}$ & $\begin{array}{l}54(47.8) \\
59(52.2)\end{array}$ & $\begin{array}{l}1 \\
0.57 \\
(0.31-1.05)\end{array}$ & 0.07145 \\
\hline Log-additive & $0,1,2$ & $70(38.3)$ & $113(61.7)$ & $\begin{array}{l}1.92 \\
(1.25-2.96)\end{array}$ & $0.00232 *$ \\
\hline
\end{tabular}

The genotype frequencies of PADI4 polymorphism were $30 \% \mathrm{C} / \mathrm{C}, 45.7 \% \mathrm{C} / \mathrm{T}$, and $17 \%$ $\mathrm{T} / \mathrm{T}$ in the RA patients group and $40.7 \% \mathrm{C} / \mathrm{C}, 42.5 \%$ $\mathrm{C} / \mathrm{T}$, and $16.8 \% \mathrm{~T} / \mathrm{T}$ in the control group ( $\mathrm{p}>0.05$; Supplementary Table 4).

The frequencies of the PTPN22 polymorphism were 84.3\% G/G, 15.7\% A/G, and $0 \% \mathrm{~A} / \mathrm{A}$ in the RA patients group and $88.5 \% \mathrm{G} / \mathrm{G}, 10.6 \% \mathrm{~A} / \mathrm{G}$, and $0.9 \% \mathrm{~A} / \mathrm{A}$ in the control group ( $p>0.05$; Supplementary Table 5).

Theanalysis ofPADI4 andPTPN22genotype frequencies did not reveal any association with the disease by all models of inheritance ( $p>0.05$ Supplementary Tables 4 and 5).
When compared to RF status stratification, no significant association was seen between RF levels and allele and genotype frequencies of all three SNPs between patients with RF-positive and RF-negative RA (Supplementary Table 6).

Table 6: Genotypic and allelic frequencies of PADI4, PTPN22, and HLADRB9 among patients with ACPA-positive and ACPAnegative RA

\begin{tabular}{lllll}
\hline SNP, genotypes, and alleles & ACPA positive & ACPA negative & OR $(95 \% \mathrm{Cl})$ & p value \\
\hline rs9268839 HLA-DRB9 & & & & \\
G/G & $17(47.2 \%)$ & $10(29.4 \%)$ & 1 & 0.24338 \\
A/G & $13(36.1 \%)$ & $14(41.2 \%)$ & 0.55 & \\
& & & $(0.18-1.62)$ & \\
A/A & $6(16.7 \%)$ & $10(29.4 \%)$ & $0.35(0.1-1.27)$ & \\
G & $47(65.3 \%)$ & $34(50 \%)$ & 0.534 & 0.0869 \\
A & $25(34.7 \%)$ & $34(50 \%)$ & $(0.255-1.107)$ & \\
rs2240340 PADI4* & & & & $0.00115^{*}$ \\
C/C & $8(22.2 \%)$ & $13(38.2 \%)$ & 1 & \\
C/T & $13(36.1 \%)$ & $19(55.9 \%)$ & 1.11 & \\
T/T & & & $(0.36-3.44)$ & \\
& $15(41.7 \%)$ & $2(5.9 \%)$ & 12.19 & \\
C & & & $(2.19-67.94)$ & \multirow{2}{*}{$0.00244 *$} \\
T & $29(40.3 \%)$ & $45(66.2 \%)$ & 2.878 & \\
rs2476601 PTPN22 & $43(59.7 \%)$ & $23(33.8 \%)$ & $(1.38-6.129)$ & \\
G/G & & & & 0.82162 \\
A/G & $30(83.3 \%)$ & $29(85.3 \%)$ & 1 & 1.16 \\
G & $6(16.7 \%)$ & $5(14.7 \%)$ & $(0.32-4.22)$ & \\
& $66(91.7 \%)$ & $63(92.6 \%)$ & 1.144 & 1 \\
\hline
\end{tabular}

Analyzing the data according to ACPA status, a strong association between ACPA profile and PADI4 was detected ( $p<0.05$; Table 6$)$. A strong association was found between the PADI4 T allele and ACPA-positive $\mathrm{RA}(\mathrm{OR}=2.878$ [95\% Cl 1.38-6.129], $p=0.00244)$. In addition, a significant association was found between the T/T genotype of PADI4 and ACPA-positive RA, which accounted for $41.7 \%$ of patients with RA (OR $=12.19$ [95\% Cl 2.19-67.94], $p=0.00115)$.

No significant associations were found between the demographic, clinical, and laboratory characteristics of RA patients and PADI4, PTPN22, and HLA-DRB9 frequencies (data are not shown).

\section{Discussion}

In the current study, we identified the epidemiological trends of RA in the Kazakhstan population from 2017 to 2019 , those can be applicable to other countries in Central Asia. Our results showed a prevalence of RA in Kazakhstan in 2017-2019 of $0.36 \%-0.38 \%$. These findings can be compared to data on worldwide RA prevalence rates. In European countries, RA prevalence is $0.31 \%$ in France [32] $0.35 \%$ in Serbia [33], $0.33-0.41 \%$ in Italy [34], $0.5 \%$ in Spain [35], 0.56\% in Turkey [36], 0.61\% in Russia [37], $0.8 \%$ in Finland [23], $0.85 \%$ in England [38], and $0.9 \%$ in Poland [22]. The RA prevalence rate in Canada is $0.9 \%$ [39], similar to Poland, and the prevalence rate in the US is $0.54 \%$ [40]. The overall prevalence of RA 
in Africa is $0.36 \%$ [5], [23], with $0.13 \%$ in Algeria [41], $0.2 \%$ in Egypt, $0.9 \%$ in South Africa and Congo, and $0.5 \%$ in Nigeria [42]. The RA prevalence in Asia varies by country. The disease prevalence has been calculated to be $0.142 \%$ in Pakistan [43], [44], $0.27 \%$ in South Korea [45], 0.2\% in China [13], [46], and 0.75\% in Japan [47] and India [13]. The prevalence results found in our study are similar to those found in Africa as well as certain European countries including France, Serbia, and Italy. According to our results, the incidence rate of RA in Kazakhstan is $0.087 \%$, which is close to the incidence rate in Denmark of $0.078 \%$ [48] and 2 times higher than the incidence in Sweden of $0.041 \%$ [49] and in South Korea of $0.042 \%$ [45]. Regarding gender, RA prevalence showed a female-to-male ratio of $3: 1$, which coincides with global trends [6], [12], [13]. Our results also showed an increase in RA prevalence and incidence rates among women from 2017 to 2019, which is consistent with the data of Myasoedova et al. [19]. The results of our study indicated a higher RA prevalence in the southern regions of the country compared to the northern regions; this is in contrast to European study results, which showed that South European countries have a lower incidence of RA compared to northern countries [7].

Several previous studies have reported on the role of various genetic factors in RA development. The strong association of RA with Class II $\mathrm{MHC}$ / HLA-DR has been shown in multiple studies [50], [51]. The HLA-DRB1 is the most studied gene and has been found to have a significant association with RA disease severity. Other non-HLA genes may also induce susceptibility to RA. Among non-HLA loci genes, the PTPN22 and PADI4 are highly associated with RA development [6], [50], [52]. In our study, we investigated the distribution of HLA-DRB9 as a representative of the MHC complex and PTPN22 and PADI4 as representatives of non-HLA genes.

HLA DRB9 (pseudogene; cytogenetic region: 6p21.32), has been associated with RA [53]. HLADRB9 rs9268839(G) was the variant most strongly associated in Europeans with risk for RA in a genomewide association study of approximately 30,000 patients (OR 2.47, Cl: 2.39-2.55, $p=0.00001$ ) [53]. This SNP has been shown to confer a risk for RA development mostly in the Caucasian population [54]. Our study identified a significant predominance of $G$ allele and GG genotype of HLA-DRB9 rs9268839 in RA patients group, which agrees with previous reports by Okada et al. [54], [55], Newton et al. [56], Kampstra et al. [57], and Nabi et al. [58].

PTPN22 is a widely distributed gene among RA patients of European descent [59], [60]. This gene has also been associated with the risk of other autoimmune disorders. Several studies have documented the correlation of this gene polymorphism with RF-positive, ACPA-positive RA, and as a result, poor disease prognosis [60], [61]. Our study did not find a significant association between the PTPN22 polymorphism and $\mathrm{RA}$ in our sample. This is consistent with the studies by Sahin et al. in Turkey [62], Allam et al. in Algeria [26], and Plant et al. in Crete, Greece [27]. The meta-analysis by $\mathrm{Nabi}$ et al. indicated that this gene polymorphism was associated with RA susceptibility in Caucasian populations but not in the Asian population [58].

PADI4 is located on chromosome 1p36 and encodes the enzymes responsible for the arginine to citrulline conversion [10], which, in turn, promotes the synthesis of ACPA. ACPA is known to be a culprit in RA emergence, as these autoantibodies have been found in the synovial fluid of RA patients [63], [64]. The PADI4 polymorphism (rs2240340 T/C) was correlated with the development of RA in patients of Asian descent, particularly in Korean, Chinese, and Japanese populations [65]. According to Suzuki et al., PADI4 is a risk factor for early joint destruction in RA patients [66]. In our study, however, we did not find an association between PADI4 and RA susceptibility when analyzing genotype and allelic distribution between RA patients and healthy subjects, which is in agreement with the study by Martinez et al. on the Spanish population [67], Hassine et al. on the Tunisian population [68], and Allam et al. on the Algerian population [26]. However, we did identify a significant association between the PADI4 $\mathrm{T}$ allele and $\mathrm{T} / \mathrm{T}$ genotype with ACPA-positive RA, which is consistent with the study by Too et al. on an Asian population [65] and Panati et al. on the Indian population [69], though is in contrast to the study by Cantaert et al., which declared no association between PADI4 polymorphisms and ACPA [70].

It should be taken into consideration that our study had some limitations, which necessitate careful interpretation of our results. The sample size of the RA patient and control groups could affect the power of genetic association. The replication of this study on a larger sample is necessary to confirm and expand our results. The recruitment of the study participants was carried out during the COVID-19 pandemic, so the immunosuppressive therapy of the patients and general public concern was the main constraint during the recruitment process.

\section{Conclusion}

The present study provides information on RA epidemiology in Kazakhstan for 2017-2019, which can be comparable to data of other countries in Central Asia. Data analysis showed an increase in RA prevalence with age among females and a higher crude prevalence and incidence of RA in the southern regions of Kazakhstan. The results of SNP analysis revealed the significant predominance of HLA-DRB9 (rs9268839) G allele and G/G genotype frequencies in our RA patient sample. 
We also revealed the PADI4 (rs2240340) T allele and $\mathrm{T} / \mathrm{T}$ genotype association with ACPA-positive RA in our sample. Further studies on larger samples are required to confirm our obtained results and expand the data on genetics in the Kazakhstan population.

\section{References}

1. Wang L, Wang FS, Gershwin ME. Human autoimmune diseases: A comprehensive update. J Intern Med. 2015;278(4):369-95.

PMid:26212387

2. Nogaeva MG, Tuleutayeva AS. Prevalence of rheumatoid arthritis in the Republic of Kazakhstan in 2013-2017. Medicine. 2019;3:201.

3. Cross M, Smith E, Hoy D, Carmona L, Wolfe F, Vos T, et al. The global burden of rheumatoid arthritis: Estimates from the Global Burden of Disease 2010 study. Ann Rheum Dis. 2014;73(7):131622. https://doi.org/10.1136/annrheumdis-2013-20462 PMid:24550173

4. SafiriS, KolahiAA, Hoy D, Smith E, Bettampadi D, Mansournia MA, et al. Global, regional and national burden of rheumatoid arthritis 1990-2017: A systematic analysis of the global burden of disease study 2017. Ann Rheum Dis. 2019;78(11):1463-71. https://doi.org/10.1136/annrheumdis-2019-215920

PMid:31511227

5. Almoallim H, Al Saleh J, Badsha H, Ahmed HM, Habjoka S, Menassa JA, et al. A review of the prevalence and unmet needs in the management of rheumatoid arthritis in Africa and the Middle East. Rheumatol Ther. 2021;8:1-16. https://doi. org/10.1007/s40744-020-00252-1

6. Smolen JS, Aletaha D, McInnes IB. Rheumatoid arthritis. Lancet. 2016;388(10055):2023-38. https://doi.org/10.1016/ s0140-6736(16)30173-8

\section{PMid:27156434}

7. Alamanos $\mathrm{Y}$, Voulgari PV, Drosos AA. Incidence and prevalence of rheumatoid arthritis, based on the 1987 American college of rheumatology criteria: A systematic review. Semin Arthritis Rheum. 2006;36(3):182-8. https://doi.org/10.1016/j. semarthrit.2006.08.006

PMid: 17045630

8. Tobón GJ, Youinou P, Saraux A. The environment, geoepidemiology, and autoimmune disease: Rheumatoid arthritis. J Autoimmun. 2010;35(1):10-4. https://doi.org/10.1016/j. autrev.2009.11.019

PMid:20080387

9. Myasoedova E, Davis JM, Crowson CS, Gabriel SE. Epidemiology of rheumatoid arthritis: Rheumatoid arthritis and mortality. Curr Rheumatol Rep. 2010;12(5):379-85. https://doi. org/10.1007/s11926-010-0117-y

PMid:20645137

10. Crowson CS, Matteson EL, Myasoedova E, Michet CJ, Ernste FC, Warrington $\mathrm{KJ}$, et al. The lifetime risk of adultonset rheumatoid arthritis and other inflammatory autoimmune rheumatic diseases. Arthritis Rheum. 2011;63(3):633-9. https:// doi.org/10.1002/art.30155.

PMid:21360492

11. Deane KD. Best practice and research clinical rheumatology can rheumatoid arthritis be prevented? Best Pract Res Clin Rheumatol. 2013;27(4):467-85. https://doi.org/10.1016/j. berh.2013.09.002
12. van der Woude $\mathrm{D}$, van der Helm-van Mil AH. Update on the epidemiology, risk factors, and disease outcomes of rheumatoid arthritis. Best Pract Res Clin Rheumatol. 2018;32(2):174-87. https://doi.org/10.1016/j.berh.2018.10.005 PMid:30527425

13. Oton $T$, Carmona $L$. The epidemiology of established rheumatoid arthritis. Best Pract Res Clin Rheumatol. 2020;33(5):101477. https://doi.org/10.1016/j.berh.2019.101477 PMid:31987685

14. Kvien TK, Uhlig T, Ødegård S, Heiberg MS. Epidemiologica aspects of rheumatoid arthritis: The sex ratio. Ann N Y Acad Sci. 2006;1069:212-22.

PMid: 16855148

15. Demoruelle MK, Deane KD, Holers VM. When and where does inflammation begin in rheumatoid arthritis? Curr Opin Rheumatol. 2014;26(1):64-71. https://doi.org/10.1097/ bor. 0000000000000017

PMid:24247116

16. Lora V, Cerroni L, Cota C. Skin manifestations of rheumatoid arthritis. G Ital Dermatol Venereol. 2018;153(2):243-55. https:// doi.org/10.23736/s0392-0488.18.05872-8 PMid:29368864

17. Ismaili H, Ismaili L, Rexhepi M. Values and correlations between C-reactive protein and apolipoprotein B after treatment with methotrexate at patients with rheumatoid arthritis. Open Access Maced J Med Sci. 2019;7(8):1293-8. https://doi.org/10.3889/ oamjms.2019.278 PMid:31110572

18. An JJ, Nyarko E, Hamad MA. Prevalence of comorbidities and their associations with health-related quality of life and healthcare expenditures in patients with rheumatoid arthritis. Clin Rheumatol. 2019;38(10):2717-26. https://doi.org/10.1007/ s10067-019-04613-2

PMid:31134504

19. Myasoedova E, Crowson CS, Kremers HM, Therneau TM, Gabriel SE. Is the incidence of rheumatoid arthritis rising? Results from Olmsted County, Minnesota, 1955-2007. Arthritis Rheum. 2010;62(6):1576-82. https://doi.org/10.1002/art.27425 PMid:20191579

20. Minichiello E, Semerano L, Boissier MC. Time trends in the incidence, prevalence, and severity of rheumatoid arthritis: Asystematic literature review. Joint Bone Spine. 2016;83(6):62530. https://doi.org/10.1016/j.jbspin.2016.07.007 PMid:27616690

21. Silman AJ, Ollier W, Holligan S, Birrell F, Adebajo A, Asuzu MC, et al. Absence of rheumatoid arthritis in a rural Nigerian population. J Rheumatol. 1993;20(4):618-22. PMid:8496853

22. Batko B, Stajszczyk M, Świerkot J, Urbański K, Raciborski F, Jędrzejewski M, et al. Prevalence and clinical characteristics of rheumatoid arthritis in Poland: A nationwide study. Arch Med Sci. 2019;15(1):134-40. https://doi.org/10.5114/aoms.2017.71371 PMid:30697263

23. Rudan I, Sidhu S, Papana A, Meng SJ, Xin-Wei Y, Wang W, et al. Prevalence of rheumatoid arthritis in low- and middleincome countries: A systematic review and analysis. J Glob Health. 2015;5(1):010409.

PMid:25969732

24. Bax M, Van Heemst J, Huizinga TW, Toes RE. Genetics of rheumatoid arthritis: What have we learned? Immunogenetics. 2011;63(8):459-66. https://doi.org/10.1007/s00251-011-0528-6 PMid:21556860

25. Stahl EA, Raychaudhuri S, Remmers EF, Xie G, Eyre $\mathrm{S}$, Thomson BP, et al. Genome-wide association study 
meta-analysis identifies seven new rheumatoid arthritis risk loci. Nat Genet. 2010;42(6):508-14.

PMid:20453842

26. Allam I, Gharnaout M, Louahchi S, Raaf N, Kheldoun N Ladjouze A, Djidjik R. Association study of PTPN22 (rs2476601) and PADI4 (rs2240340) polymorphisms with rheumatoid arthritis in Algerian population. J Clin Cell Immunol. 2020;1(1):586.

27. Plant D, Flynn E, Mbarek H, Dieudé P, Cornelis F, Ärlestig L, et al. Investigation of potential non-HLA rheumatoid arthritis susceptibility loci in a European cohort increases the evidence for nine markers. Ann Rheum Dis. 2010;69(8):1548-53. https:// doi.org/10.1136/ard.2009.121020

\section{PMid:20498205}

28. Report on the Number of Diseases Registered in the Area of Service of the Medical Organization and the Contingents of Patients under Dispensary Supervision 2017-2019. Kazakhstan: Med-Inform. Available from: http://www.medinfo.kz.

29. Agency of Strategic Planning and Reforms of the Republic of Kazakhstan Bereau of National Statistics. Available from: https://www.stat.gov.kz.

30. Prevoo ML, van't Hof, MA, Kuper $H H$, van Rijswijk MA, van Leeuwen $\mathrm{MH}$, van de Putte $\mathrm{LB}$, et al. Modified disease activity scores that include twenty-eight-joint counts. development and validation in a prospective longitudinal study of patients with rheumatoid arthritis. Arthritis Rheum. 1995;38(1):44-8. https:// doi.org/10.1002/art.1780380107 PMid:7818570

31. Fries JM, Spitz P, Kraines RG, Holman HR. Measurement of patient outcome in arthritis. Arthritis Rheum. 1980;23(2):137-45. https://doi.org/10.1002/art.1780230202

\section{PMid:7362664}

32. Roux $\mathrm{CH}$, Saraux A, Le Bihan E, Fardellone $P$, Guggenbuhl $P$ Fautrel B, et al. Rheumatoid arthritis and spondyloarthropathies: Geographical variations in prevalence in FranceTitle. J Rheumatol. 2007;34(1):117-122.

PMid:17117490

33. Zlatković-Švenda MI, Stojanović RM, Šipetić-Grujičić SB, Guillemin F. Prevalence of rheumatoid arthritis in Serbia. Rheumatol Int. 2014;34(5):649-58. https://doi.org/10.1007/ s00296-013-2897-7

PMid:24292809

34. Rossini M, Rossi E, Bernardi D, Viapiana O, Gatti D, Idolazzi L, et al. Prevalence and incidence of rheumatoid arthritis in Italy. Rheumatol Int. 2014;34(5):659-64. https://doi.org/10.1007/ s00296-014-2974-6

PMid:24610538

35. Seoane-Mato D, Sánchez-Piedra C, Silva-Fernández L, Sivera F, Blanco FJ, Pérez Ruiz F, et al. Prevalence of rheumatic diseases in adult population in Spain (EPISER 2016 study): Aims and methodology. Reumatol Clin. 2019;15(2):90-6. https:// doi.org/10.1136/annrheumdis-2018-eular.6463 PMid:28774657

36. Tunser T, Gilgil E, Kacar C, Kurtais I, Kutlay S, Bütün B, et al. Prevalence of rheumatoid arthritis and spondyloarthritis in Turkey: A nationwide study. Arch Rheumatol. 2018;33(2):12836. https://doi.org/10.5606/archrheumatol.2018.6480

37. Galushko EA, Nasonov EL. Prevalence of rheumatic diseases in Russia. Alm Clin Med. 2018;46(1):32-9.

38. Humphreys JH, Verstappen SM, Hyrich KL, Chipping JR, Marshall T, Symmons DP. The incidence of rheumatoid arthritis in the UK: Comparisons using the 2010 ACR/EULAR classification criteria and the 1987 ACR classification criteria. Results from the Norfolk Arthritis Register. Ann Rheum Dis. 2013;72(8):131520. https://doi.org/10.1136/annrheumdis-2012-201960 PMid:22945499
39. Widdifield J, Paterson JM, Bernatsky S, Tu K, Tomlinson G, Kuriya B, et al. The epidemiology of rheumatoid arthritis in Ontario, Canada. Arthritis Rheumatol. 2014;66(4):786-93. https://doi.org/10.1002/art.38306 PMid:24757131

40. Hunter TM, Boytsov NN, Zhang X, Schroeder K, Michaud K, Araujo AB. Prevalence of rheumatoid arthritis in the United States adult population in healthcare claims databases, 2004-2014. Rheumatol Int. 2017;37(9):1551-7. https://doi. org/10.1007/s00296-017-3726-1

PMid:28455559

41. Slimani S, Ladjouze-Rezig A. Prevalence of rheumatoid arthritis in an urban population of Algeria: A prospective study. Rheumatol (United Kingdom). 2014;53(3):571-3. https://doi. org/10.1093/rheumatology/ket446

PMid:24425779

42. Essouma M, Nkeck JR, Endomba FT, Bigna JJ, Ralandison S. Epidemiology of rheumatoid arthritis in sub-Saharan Africa: A systematic review and meta-analysis protocol. Syst Rev. 2020;9(1):81. https://doi.org/10.1186/s13643-020-01342-5 PMid:32303250

43. Naqvi AA, Hassali MA, Aftab MT. Epidemiology of rheumatoid arthritis, clinical aspects and socio-economic determinants in Pakistani patients: A systematic review and meta-analysis. J Pak Med Assoc. 2019;69(3):389-98. PMid:30890833

44. Aslam MM, John P, Fan K, Bhatti A, Aziz W, Ahmed B, et al. Investigating the GWAS-implicated loci for rheumatoid arthritis in the pakistani population. Dis Markers. 2020;2020:1910215. https://doi.org/10.1155/2020/1910215

45. Sung YK, Cho SK, Choi CB, Bae SC. Prevalence and incidence of rheumatoid arthritis in South Korea. Rheumatol Int. 2013;33(6):1525-32. https://doi.org/10.1007/ s00296-012-2590-2

PMid:23255140

46. Silman AJ, Pearson JE, Silman AJ, Pearson JE. Epidemiology and genetics of rheumatoid arthritis. Arthritis Res Ther. 2002;4(S3):265-72.

PMid:12110146

47. Kojima M, Nakayama T, Tsutani K, Igarashi A, Kojima T, Suzuki S, et al. Epidemiological characteristics of rheumatoid arthritis in Japan: Prevalence estimates using a nationwide population-based questionnaire survey. Mod Rheumatol. 2020;30(6):941-7. https://doi.org/10.1080/14397595.2019.1682 776

\section{PMid:31625435}

48. Pedersen JK, Svendsen AJ, Hørslev-Petersen k. Incidence of rheumatoid arthri- tis in the southern part of Denmark from 1995 to 2001. Open Rheumatol J. 2007;1:18-23. https://doi. org/10.2174/1874312900701010018

PMid:19088896

49. Eriksson JK, Neovius M, Ernestam S, Lindblad S, Simard JF, Askling J. Incidence of rheumatoid arthritis in Sweden: A Nationwide population-based assessment of incidence, its determinants, and treatment penetration. Arthritis Care Res. 2013;65(6):870-8. https://doi.org/10.1002/acr.21900 PMid:23281173

50. Karami J, Aslani S, Jamshidi A, Garshasbi M, Mahmoudi M. Genetic implications in the pathogenesis of rheumatoid arthritis: An updated review. Gene. 2019;702:8-16. https://doi. org/10.1016/j.gene.2019.03.033 PMid:30904715.

51. Traylor M, Curtis C, Patel H, Breen G, Hyuck S, Xu X, et al. Original article Genetic and environmental risk factors for rheumatoid arthritis in a UK African ancestry population: The 
GENRA case control study. 2017;56(8):1282-92. https://doi. org/10.1093/rheumatology/kex048

PMid:28407095

52. Korczowska I. Rheumatoid arthritis susceptibility genes: An overview. World J Orthop. 2014:5(4):544-9. https://doi. org/10.5312/wjo.v5.i4.544

PMid:25232530

53. Okada Y, Kim K, Han B, Pillai NE, Ong RT, Saw WY, et al. Risk for ACPA-positive rheumatoid arthritis is driven by shared HLA amino acid polymorphisms in Asian and European populations. Hum Mol Genet. 2014;23(25):6916-26. http:// dx.doi.org/10.1093/hmg/ddu387.

PMid:25070946

54. Okada Y, Wu D, Trynka G, Raj T, Terao C, Ikari K, et al. Genetics of rheumatoid arthritis contributes to biology and drug discovery. Nature. 2014:506(7488):376-81.

PMid:24390342

55. Yamamoto K, Okada Y, Suzuki A, Kochi Y. Genetics of rheumatoid arthritis in Asia present and future. Nat Publ Gr. 2015;11(6):375-9. https://doi.org/10.1038/nrrheum.2015.7 PMid:25668139

56. Newton JL, Harney SM, Wordsworth BP, Brown MA. A review of the MHC genetics of rheumatoid arthritis., Genes Immunity. 200;5(3):151-7. https://doi.org/10.1038/sj.gene.6364045 PMid: 14749714

57. Kampstra A, Toes R. HLA class II and rheumatoid arthritis: The bumpy road of revelation. Immunogenetics. 2017;69(8-9):597603. https://doi.org/10.1007/s00251-017-0987-5 PMid:28695293

58. Nabi G, Akhter N, Wahid M, Bhatia K, Mandal RK, Dar SA, et al. Meta-analysis reveals PTPN22 1858C/T polymorphism confers susceptibility to rheumatoid arthritis in Caucasian but not in Asian population. Autoimmunity. 2016;49(3):197-210. https:// doi.org/10.3109/08916934.2015.1134514

PMid:26763276

59. Schulz S, Zimmer P, Pütz N, Jurianz E, Schaller HG, Reichert S. rs2476601 in PTPN22 gene in rheumatoid arthritis and periodontitis a possible interface ? J TransI Med. 2020;18(1):389. https://doi.org/10.1186/s12967-020-02548-w PMid:33059697

60. Kurkó J, Besenyei T, Laki J, Glant TT, Mikecz K, Szekanecz Z. Genetics of rheumatoid arthritis a comprehensive review. Clin Rev Allergy Immunol. 2013;45(2):170-9. https://doi.org/10.1007/ s12016-012-8346-7

PMid:23288628

61. Mustelin T, Bottini N, Stanford SM. The contribution of PTPN22 to rheumatic disease. Arthritis Rheumatol. 2019;71(4):486-95. https://doi.org/10.1002/art.40790

PMid:30507064
62. Sahin N, Gunduz F, Inanc N, Direskeneli H, SaruhanDireskeneli G. No association of PTPN22 gene polymorphism with rheumatoid arthritis in Turkey. Rheumatol Int. 2009;30:813. https://doi.org/10.1007/s00296-009-0919-2

63. Baños-Hernández CJ, Navarro-Zarza JE, Parra-Rojas I, Vázquez-Villamar M, Padilla-Gutiérrez JR, Valle Y, et al. PADI4 polymorphisms and the functional haplotype are associated with increased rheumatoid arthritis susceptibility : A replication study in a Southern Mexican population. Hum Imunol. 2017;78(9): 553-8. https://doi.org/10.1016/j.humimm.2017.05.005 PMid:28551357

64. Lu C, Xu K, Guo H, Peng K, Yang Z, Hao YQ, et al. The relationship of PADI4_94 polymorphisms with the morbidity of rheumatoid arthritis in Caucasian and Asian populations: A meta-analysis and system review. 2018;37(2): 289-96. https:// doi.org/10.1007/s10067-017-3964-3

PMid:29302826

65. Too CL, Murad S, Dhaliwal JS, Larsson P, Jiang X, Ding B, et al. Polymorphisms in peptidylarginine deiminase associate with rheumatoid arthritis in diverse Asian populations: Evidence from MyEIRA study and meta-analysis. Arthritis Res Ther. 2012;14:R250. https://doi.org/10.1186/ar4093

66. Suzuki T, Ikari K, Yano K, Inoue E, Toyama Y, Taniguchi A. PADI4 and HLA-DRB1 are genetic risks for radiographic progression in RA patients, independent of ACPA status: Results from the IORRA cohort study. PLoS One. 2013;8(4):e61045. https://doi. org/10.1371/journal.pone.0061045 PMid:23577190

67. Martinez A, Valdivia A, Pascual-Salcedo D, Lamas JR, Fernández-Arquero $\mathrm{M}$, Balsa $\mathrm{A}$, et al. PADI4 polymorphisms are not associated with rheumatoid arthritis in the Spanish population. Rheumatology. 2005:44(10):1263-6. https://doi. org/10.1093/rheumatology/kei008

PMid:15998632

68. Ben Hassine $H$, Zemni R, Bouagina E, Zaglaoui $H$, Ben Fradj $\mathrm{H}$, Slama $\mathrm{F}$, et al. Lack of association between PADI4 polymorphisms and rheumatoid arthritis in the Tunisian population. Joint Bone Spine. 2012;79(3):329-30. https://doi. org/10.1016/j.jbspin.2011.11.005

PMid:22459419

69. Panati K, Pal S, Rao K V, Reddy VD. Association of single nucleotide polymorphisms (SNPs) of PADI4 gene with rheumatoid arthritis (RA) in Indian population. 2012;87(3):1916. https://doi.org/10.1266/ggs.87.191

PMid:22976394

70. Cantaert T, Coucke P, De Rycke L, Veys EM, De Keyser F, Baeten D. Functional haplotypes of PADI4: Relevance for rheumatoid arthritis specific synovial intracellular citrullinated proteins and anticitrullinated protein antibodies. Ann Rheum Dis. 2005;64(9):1316-20. https://doi.org/10.1136/ard.2004.033548 PMid:15760928. 


\section{Supplementary}

Supplementary Table 1: Prevalence of RA per 100,000 population in 2017-2019 according to age and gender

\begin{tabular}{|c|c|c|c|c|}
\hline \multirow[t]{3}{*}{ Year } & \multicolumn{4}{|c|}{ Age group } \\
\hline & \multicolumn{2}{|c|}{$18-59$} & \multicolumn{2}{|c|}{60 years and older } \\
\hline & Male & Female & Male & Female \\
\hline 2017 & 270 & 1003 & 789 & 1183 \\
\hline 2018 & 264 & 956 & 812 & 1202 \\
\hline 2019 & 304 & 1005 & 902 & 1218 \\
\hline
\end{tabular}

Supplementary Table 2: Prevalence of RA by regions of Kazakhstan in 2017-2019

\begin{tabular}{|c|c|c|c|c|c|c|c|c|c|}
\hline \multicolumn{10}{|c|}{ Prevalence per 100,000 population } \\
\hline \multirow[t]{2}{*}{ Region } & \multicolumn{3}{|l|}{2017} & \multicolumn{3}{|l|}{2018} & \multicolumn{3}{|l|}{2019} \\
\hline & Total & Female & Male & Total & Female & Male & Total & Female & Male \\
\hline Akmola & 282.6 & 428.7 & 127.3 & 311.8 & 439.4 & 176.5 & 469.3 & 661.9 & 265.3 \\
\hline Aktobe & 217.9 & 319.5 & 109.6 & 268.3 & 387.4 & 141.5 & 274.9 & 393.3 & 149.2 \\
\hline Almatinskaya & 338.0 & 509.2 & 163.2 & 331.1 & 488.2 & 171.2 & 325.1 & 478.3 & 168.4 \\
\hline Almaty & 505.2 & 761.5 & 199.9 & 517.2 & 775.1 & 210.5 & 530.1 & 777.5 & 238.4 \\
\hline Atyrau & 176.6 & 197.7 & 154.7 & 183.8 & 207.0 & 160.0 & 208.3 & 267.8 & 147.1 \\
\hline East & 329.4 & 481.6 & 162.3 & 344.4 & 516.9 & 155.4 & 372.9 & 530.8 & 200.2 \\
\hline \multicolumn{10}{|l|}{ Kazakhstan } \\
\hline Zhambyl & 446.6 & 689.7 & 195.6 & 433.0 & 667.2 & 191.6 & 448.3 & 654.9 & 235.8 \\
\hline West & 225.9 & 350.4 & 93.5 & 238.0 & 368.7 & 98.9 & 255.8 & 385.1 & 118.6 \\
\hline \multicolumn{10}{|l|}{ Kazakhstan } \\
\hline Karaganda & 187.6 & 265.4 & 101.3 & 211.7 & 297.0 & 117.4 & 243.9 & 343.8 & 133.5 \\
\hline Kyzylorda & 289.1 & 446.9 & 131.8 & 350.9 & 537.5 & 165.4 & 347.3 & 525.3 & 170.6 \\
\hline Kostanay & 238.3 & 339.2 & 126.4 & 236.2 & 354.7 & 105.2 & 244.4 & 362.5 & 113.9 \\
\hline Mangystau & 207.5 & 321.9 & 92.1 & 243.0 & 427.9 & 56.8 & 252.1 & 357.9 & 145.6 \\
\hline Nur-Sultan & 470.1 & 749.7 & 168.8 & 415.6 & 666.2 & 144.1 & 432.3 & 692.1 & 150.8 \\
\hline Pavlodar & 403.12 & 585.5 & 199.6 & 323.4 & 482.4 & 146.6 & 327.3 & 491.1 & 145.4 \\
\hline North & 323.5 & 459.1 & 175.3 & 328.2 & 486.0 & 156.1 & 327.3 & 483.2 & 157.3 \\
\hline \multicolumn{10}{|l|}{ Kazakhstan } \\
\hline Turkistan & - & - & - & 418 & 629.2 & 212.7 & 435.6 & 638.5 & 238.4 \\
\hline Shymkent & - & - & - & 682.0 & 1067.1 & 265.0 & 708.7 & 1108.2 & 279.4 \\
\hline South & 625.9 & 991.4 & 277.1 & - & - & - & - & - & - \\
\hline \multicolumn{10}{|l|}{ Kazakhstan } \\
\hline (Turk. + & & & & & & & & & \\
\hline Shymkent) & & & & & & & & & \\
\hline
\end{tabular}

Supplementary Table 3: Incidence of RA by regions of Kazakhstan in 2017-2019

\begin{tabular}{|c|c|c|c|c|c|c|c|c|c|}
\hline \multicolumn{10}{|c|}{ Incidence per 100,000 population } \\
\hline \multirow[t]{2}{*}{ Region } & \multicolumn{3}{|l|}{2017} & \multicolumn{3}{|l|}{2018} & \multicolumn{3}{|l|}{2019} \\
\hline & Total & Female & Male & Total & Female & Male & Total & Female & Male \\
\hline Akmola & 38.7 & 54.4 & 22.1 & 39.7 & 48.1 & 30.7 & 51.2 & 59.4 & 42.5 \\
\hline Aktobe & 45 & 48.4 & 41.4 & 54.7 & 67.8 & 40.8 & 72.8 & 99.1 & 44.9 \\
\hline Almatinskaya & 87.5 & 121.3 & 52.9 & 87.3 & 114.6 & 59.5 & 85.7 & 112.3 & 58.4 \\
\hline Almaty & 134.3 & 196.1 & 60.8 & 128.9 & 190.7 & 55.3 & 133.8 & 188.6 & 69.2 \\
\hline Atyrau & 55.3 & 82.2 & 27.4 & 63.9 & 88.4 & 38.7 & 103.8 & 176.7 & 28.9 \\
\hline East & 48.9 & 69.9 & 26.1 & 58.0 & 82.3 & 31.5 & 44.7 & 63.6 & 24.0 \\
\hline \multicolumn{10}{|l|}{ Kazakhstan } \\
\hline Zhambyl & 143.8 & 207.7 & 77.9 & 136.7 & 193.8 & 77.9 & 138.2 & 207.2 & 67.3 \\
\hline West & 28.8 & 40.8 & 15.9 & 36.2 & 53.9 & 17.4 & 32.7 & 44.1 & 20.7 \\
\hline \multicolumn{10}{|l|}{ Kazakhstan } \\
\hline Karaganda & 18.8 & 23.7 & 13.3 & 26.0 & 33.7 & 17.4 & 24.8 & 26.4 & 22.9 \\
\hline Kyzylorda & 92.9 & 141.2 & 44.9 & 107.8 & 160.1 & 55.7 & 96.4 & 138.1 & 55.1 \\
\hline Kostanay & 48.4 & 66.7 & 28.2 & 48.6 & 69.1 & 25.8 & 48.2 & 63.4 & 31.5 \\
\hline Mangystau & 57.9 & 89.3 & 26.1 & 69.4 & 117.5 & 21.0 & 59.8 & 78.4 & 41.1 \\
\hline Nur-Sultan & 111.3 & 170.6 & 47.4 & 105.4 & 161.0 & 45.2 & 101.4 & 150.6 & 48.1 \\
\hline Pavlodar & 59.6 & 81.7 & 35.0 & 53.3 & 76.3 & 27.7 & 56.8 & 76.8 & 34.5 \\
\hline North & 41.7 & 57.3 & 24.7 & 52.7 & 74.3 & 29.0 & 44.5 & 62.2 & 25.1 \\
\hline \multicolumn{10}{|l|}{ Kazakhstan } \\
\hline Turkistan & - & - & - & 76.7 & 107.3 & 46.9 & 76.5 & 108.3 & 45.6 \\
\hline Shymkent & - & - & - & 209.9 & 229.0 & 96.3 & 233.5 & 360.2 & 97.3 \\
\hline South & 139.6 & 205.7 & 72.9 & - & - & - & - & - & - \\
\hline \multicolumn{10}{|l|}{ Kazakhstan } \\
\hline (Turk. + & & & & & & & & & \\
\hline Shymkent) & & & & & & & & & \\
\hline
\end{tabular}


Supplementary Table 4: The PADI4 genotype distribution

\begin{tabular}{|c|c|c|c|c|c|}
\hline $\begin{array}{l}\text { rs2240340 } \\
\text { PADI4 }\end{array}$ & Genotypes & $\begin{array}{l}\text { RA patients } \\
(\mathrm{n}=70),(\text { abs. } \%)\end{array}$ & $\begin{array}{l}\text { Control } \\
(n=116),(\text { abs.\%) }\end{array}$ & OR 95Cl & $\mathrm{p}$ \\
\hline \multirow[t]{2}{*}{ Dominant } & $\mathrm{C} / \mathrm{C}$ & $21(30)$ & $46(40.7)$ & 1 & \multirow[t]{2}{*}{0.14133} \\
\hline & $\mathrm{C} / \mathrm{T}-\mathrm{T} / \mathrm{T}$ & 49 (70) & 67 (59.3) & $\begin{array}{l}1.6 \\
(0.85-3.02)\end{array}$ & \\
\hline \multirow[t]{3}{*}{ Codominant } & $\mathrm{C} / \mathrm{C}$ & $21(30)$ & $46(40.7)$ & 1 & \multirow[t]{3}{*}{0.26031} \\
\hline & $\mathrm{C} / \mathrm{T}$ & $32(45.7)$ & $48(42.5)$ & $\begin{array}{l}1.46 \\
(0.74-2.89)\end{array}$ & \\
\hline & $T / T$ & $17(24.3)$ & $19(16.8)$ & $\begin{array}{l}1.96 \\
(0.85-4.51)\end{array}$ & \\
\hline \multirow[t]{2}{*}{ Recessive } & $\mathrm{C} / \mathrm{C}-\mathrm{C} / \mathrm{T}$ & $53(75.7)$ & $94(83.2)$ & 1 & \multirow[t]{2}{*}{0.22056} \\
\hline & $T / T$ & $17(24.3)$ & $19(16.8)$ & $\begin{array}{l}1.59 \\
(0.76-3.31)\end{array}$ & \\
\hline \multirow[t]{2}{*}{ Overdominant } & $\mathrm{C} / \mathrm{C}-\mathrm{T} / \mathrm{T}$ & $38(54.3)$ & 65 (57.5) & 1 & \multirow[t]{2}{*}{0.66812} \\
\hline & $\mathrm{C} / \mathrm{T}$ & $32(45.7)$ & $48(42.5)$ & $\begin{array}{l}1.14 \\
(0.63-2.08)\end{array}$ & \\
\hline Log-Additive & $0,1,2$ & $70(38.3)$ & $113(61.7)$ & $\begin{array}{l}1.41 \\
(0.93-2.12)\end{array}$ & 0.10203 \\
\hline
\end{tabular}

Supplementary Table 5: The PTPN22 genotype distribution

\begin{tabular}{|c|c|c|c|c|c|}
\hline $\begin{array}{l}\text { rs2476601 } \\
\text { PTPN22 }\end{array}$ & Genotypes & $\begin{array}{l}\text { RA patients } \\
(\mathrm{n}=70),(\mathrm{abs} . \%)\end{array}$ & $\begin{array}{l}\text { Control } \\
(n=113),(\text { abs. \%) }\end{array}$ & OR $95 \mathrm{Cl}$ & $p$ \\
\hline \multirow[t]{2}{*}{ Dominant } & $\mathrm{G} / \mathrm{G}$ & $59(84.3)$ & $100(88.5)$ & 1 & \multirow[t]{2}{*}{0.41633} \\
\hline & A/G-A/A & $11(15.7)$ & $13(11.5)$ & $\begin{array}{l}1.43 \\
(0.6-3.41)\end{array}$ & \\
\hline \multirow[t]{3}{*}{ Codominant } & G/G & 59 (84.3) & $100(88.5)$ & 1 & \multirow[t]{3}{*}{0.53829} \\
\hline & $\mathrm{A} / \mathrm{G}$ & $11(15.7)$ & $12(10.6)$ & $\begin{array}{l}1.55 \\
(0.64-3.74)\end{array}$ & \\
\hline & $\mathrm{A} / \mathrm{A}$ & $0(0)$ & $1(0.9)$ & 0 (0-NA) & \\
\hline \multirow[t]{2}{*}{ Recessive } & G/G-A/G & $70(100)$ & $112(99.1)$ & 1 & \multirow[t]{2}{*}{1} \\
\hline & $\mathrm{A} / \mathrm{A}$ & $0(0)$ & $1(0.9)$ & 0 (0-NA) & \\
\hline Overdominant & $\begin{array}{l}\text { G/G-A/A } \\
A / G\end{array}$ & $\begin{array}{l}59(84.3) \\
11(15.7)\end{array}$ & $\begin{array}{l}101(89.4) \\
12(10.6)\end{array}$ & $\begin{array}{l}1 \\
1.57 \\
(0.65-3.78)\end{array}$ & 0.31736 \\
\hline Log-additive & $0,1,2$ & $70(38.3)$ & $113(61.7)$ & $\begin{array}{l}1.29 \\
(0.57-2.91)\end{array}$ & 0.53829 \\
\hline
\end{tabular}

Supplementary Table 6: Genotypic and allelic frequencies of PADI4. PTPN22 and HLADRB9 among RF (+) and RF(-) patients

\begin{tabular}{lllll}
\hline SNP and genotypes & $\mathrm{RF}(+)$ & $\mathrm{RF}(-)$ & $\mathrm{OR}(95 \% \mathrm{Cl})$ & $\mathrm{p}$ \\
\hline rs9268839 & & & & \\
G/G & $21(39.6 \%)$ & $6(35.3 \%)$ & 1 & 0.7687 \\
A/G & $21(39.6 \%)$ & $6(35.3 \%)$ & $1(0.28-3.61)$ & \\
A/A & $11(20.8 \%)$ & $5(29.4 \%)$ & $0.63(0.16-2.53)$ & \\
G & 63 & 18 & $0.769(0.329-1.808)$ & 0.552 \\
A & 43 & 16 & & \\
rs2240340 & & & & 0.27652 \\
C/C & $14(26.4 \%)$ & $7(41.2 \%)$ & 1 & \\
C/T & $24(45.3 \%)$ & $8(47.1 \%)$ & $1.5(0.45-5.03)$ & \\
T/T & $15(28.3 \%)$ & $2(11.8 \%)$ & $3.75(0.66-21.2)$ & \\
C & $52(49.1 \%)$ & $22(64.7 \%)$ & $1.895(0.802-4.662)$ & 0.12 \\
T & $54(50.9 \%)$ & $12(35.3 \%)$ & & \\
rs2476601 & & & & 0.25666 \\
G/G & $44(83 \%)$ & $15(88.2 \%)$ & 1 & 1 \\
A/G & $9(17 \%)$ & $2(11.8 \%)$ & $1.53(0.3-7.91)$ & \\
G & $97(91.5 \%)$ & $32(94.1 \%)$ & $1.481(0.285-14.79)$ & 1 \\
A & $9(8.5 \%)$ & $2(5.9 \%)$ & & \\
\hline
\end{tabular}

